\title{
Latihan Peregangan Dinamis Dan Istirahat Aktif Menurunkan Keluhan Muskuloskeletal Pada Pekerja Di Industri Garmen
}

\author{
Syavira Nooryana $^{1^{*}}$, I Putu Gede Adiatmika ${ }^{2}$, dan Susy Purnawati ${ }^{3}$ \\ 1) Program Studi Sarjana Fisioterapi, Fakultas Ilmu Kesehatan \\ Universitas Muhammadiyah, Pekalongan \\ 2) Program Studi Magister Ergonomi-Fisiologi Kerja, Universitas Udayana, Denpasar \\ 3) Departemen Ilmu Faal, Fakultas Kedokteran, Universitas Udayana, Denpasar \\ $\left.{ }^{*}\right)$ e-mail korespondensi: vira.syavira93@gmail.com \\ doi: https://doi.org/10.24843/JEI.2020.v06.i01.p08
}

Article Received: 22 November 2019; Accepted: 31 Desember 2019; Published: 30 Juni 2020

\begin{abstract}
Abstrak
Permasalahan ergonomi yang dialami pekerja bagian pengendalian mutu produk dan sablon di industri garmen Adhi Fashion antara lain pemanfaatan tenaga otot, sikap kerja, dan kondisi waktu kerja yang masih belum sesuai dengan kaidah ergonomi. Pekerja melakukan pekerjaan secara monoton dan statis dalam jangka waktu lama dengan waktu istirahat selama 60 menit perhari selama 6 hari kerja dan disertai istirahat curian. Pekerja mengalami keluhan muskuloskeletal dengan klasifikasi keluhan sedang sampai tinggi dan kategori beban kerja rendah sampai sedang. Diperlukan adanya suatu perbaikan ergonomi diantaranya pemberian latihan peregangan istirahat aktif yang dapat berpengaruh pada otototot tubuh secara keseluruhan sebagai upaya perbaikan sikap kerja dan meminimalkan terjadinya istirahat curian. Penelitian menggunakan rancangan sama subjek dengan sampel berjumlah 13 responden yang terdiri atas 8 orang pekerja bagian pengendalian mutu produk dan 5 orang pekerja bagian sablon. Semua subjek memiliki keluhan muskuloskeletal dan beban kerja pada kategori yang sama. Pada Periode 1 proses pekerjaan tanpa intervensi dan Periode 2 proses pekerjaan dengan intervensi berupa pemberian latihan peregangan dinamis dan istirahat aktif. Pengumpulan data keluhan muskuloskeletal menggunakan Nordic Body Map pada Periode 1 dan Periode 2. Uji normalitas data menggunakan uji Shapiro-Wilk, uji efek intervensi menggunakan uji Paired-Sample T dan uji Wilcoxon Signed-Rank. Setelah dilakukan latihan peregangan dinamis dan istirahat aktif didapatkan hasil yang signifikan pada penurunan keluhan muskuloskeletal $(\mathrm{p}<0,05)$. Terdapat penurunan keluhan muskuloskeletal sebesar 7,72\%. Latihan peregangan dinamis dan istirahat aktif terbukti berpengaruh terhadap penurunan keluhan muskuloskeletal pada pekerja bagian pengendalian mutu produk dan sablon di industri garmen Adhi Fashion.
\end{abstract}

Kata kunci: istirahat aktif, keluhan muskuloskeletal, latihan peregangan dinamis

\section{Dynamic Stretching Exercise And Active Rest Reduced Musculoskeletal Disorder Of Workers In Garment Industry}

\begin{abstract}
Ergonomics problems experienced by workers at quality control and screen printing department at Adhi Fashion garment industry are the use of muscle power, work posture, and work time that still not in accordance to ergonomic principle. The workers carry out static and monotonous work for a long time and got 60 minutes pause per day for 6 working days. They were observed often take disguised pause while doing their jobs. They had musculoskeletal disorder with moderate to high scale complaints and low to moderate workload. There are exercises they can do by applicating of dynamic stretching
\end{abstract}


exercise and active rest that can affect whole body muscles as an efforts to improve work posture and minimize taking of disguised pause. This study used treatment by subject design. The number of samples were 13 respondents consist of 8 workers from the quality control and 5 workers from the screen printing. At Period 1 the subject was working without intervention and Period 2 was working with intervention by applicating dynamic stretching exercise and active rest. The musculoskeletal disorder measured by the Nordic Body Map on Period 1 and Period 2. The normality of the data are tested using the Shapiro-Wilk Test. The intervention effect are tested using Paired-Sample T Test and Wilcoxon Sigend-Rank Test. Dynamic stretching exercise and active rest significantly affected to musculoskeletal complaints $(p<0.05)$. There were reduction of musculoskeletal disorder $(7.72 \%)$. Dynamic stretching exercise and active rest reduced of musculoskeletal disorder of workers at the quality control and screen printing in Adhi Fashion garment industry.

Keywords: active rest, dynamic stretching exercise, musculoskeletal disorder

\section{PENDAHULUAN}

Salah satu industri manufaktur dan industri yang masih prospektif untuk dikembangkan yaitu industri garmen. Di wilayah Denpasar banyak tumbuh industri garmen dan sedang mengalami perkembangan, salah satunya adalah konveksi Adhi Fashion. Industri ini memproduksi clothing dalam jumlah banyak setiap harinya dan bernuansa budaya yang mempertahankan keunggulan serta kearifan lokal. Industri garmen atau konveksi merupakan suatu tempat berlangsungnya perindustrian yaitu adanya interaksi antara manusia dan alatmesin, serta teknologi dan sumber daya yang dikelola dalam suatu sistem produksi untuk menghasilkan suatu produk maupun jasa.

Studi pendahuluan dilakukan untuk mengetahui kondisi lingkungan kerja di industri garmen dengan menggunakan kajian 8 aspek ergonomi. Didapatkan bahwa pemanfaatan tenaga otot, sikap kerja, dan kondisi waktu kerja pada 8 orang pekerja proses produksi bagian pengendalian mutu produk dan 5 orang pekerja proses produksi bagian sablon masih belum sesuai dengan kaidah ergonomi dibandingkan dengan pekerja pada bagian proses produksi lainnya. Pemanfaatan tenaga otot yang belum sesuai diakibatkan karena banyaknya pesanan pakaian yang harus diselesaikan, menyebabkan pekerja melakukan sikap kerja duduk dan berdiri yang kurang ergonomis. Setiap harinya lebih dari 50 pakaian dapat diselesaikan oleh seorang pekerja bagian pengendalian mutu produk dan sablon. Pekerja melakukan pekerjaannya dengan sikap kerja yang monoton dan dalam kurun waktu yang lama.

Kondisi waktu pekerja melakukan pekerjaannya pada industri ini yaitu 8 jam/hari dari pukul 08.00 WITA sampai dengan pukul 17.00 WITA, dengan waktu istirahat $60 \mathrm{menit} / \mathrm{hari}$ yaitu pada pukul 12.00 WITA sampai dengan 13.00 WITA. Berdasarkan fenomena tersebut ditemukan pekerja yang sering melakukan istirahat curian pada saat melakukan pekerjaannya. Karakteristik pekerja di industri tekstil adalah duduk maupun berdiri statis disertai dengan posisi bagian leher sampai punggung yang membungkuk dengan posisi siku dan lutut yang ditekuk.

Pengukuran sikap kerja diperlukan sebagai pemeriksaan awal yang berkaitan dengan ergonomi di tempat kerja dimana keluhan muskuloskeletal dilaporkan. Pemeriksaan tersebut dilakukan dengan menggunakan Rapid Upper Limb Assesment (RULA) dan Rapid Entire Body Assesment (REBA). Hasil pengukuran menggunakan RULA pada pekerja bagian pengendalian mutu produk didapatkan hasil rerata skor yaitu 6 (enam) yang berarti diperlukan adanya pemeriksaan lebih lanjut dan segera dilakukan perbaikan. Hasil pengukuran menggunakan REBA pada pekerja bagian sablon didapatkan hasil rerata skor yaitu 9 (sembilan) yang berarti beresiko tinggi sehingga diperlukan adanya pemeriksaan lebih lanjut dan upaya perbaikan. 
Pemeriksaan awal tersebut dijadikan sebagai acuan untuk melakukan pemeriksaan lanjutan yaitu melakukan pengukuran keluhan muskuloskeletal dengan menggunakan Nordic Body Map yang dilakukan setelah pekerja melakukan pekerjaannya. Didapatkan hasil klasifikasi tingkat risiko keluhan muskuloskeletal sedang sampai tinggi yaitu dengan nilai minimum 70 dan nilai maksimum 82. Berdasarkan penelitian Rozana dan Adiatmika (2014) menyebutkan bahwa persentase keluhan muskuloskeletal yang paling sering dikeluhkan oleh pekerja sebersar 86,05\% yaitu sakit dan kaku pada leher bawah, punggung dan pinggang. Kondisi di industri garmen sesuai dengan temuan tersebut, sehingga diperlukan suatu perbaikan.

Berdasarkan rekomendasi OSHA 3125 (2000) terdapat dua cara perbaikan ergonomi yang dapat dilakukan untuk mencegah terjadinya suatu penyakit yaitu rekayasa teknik dan rekayasa managemen. Pada industri tersebut ditemukan adanya masalah berupa sikap kerja yang kurang ergonomis yang menyebabkan timbulnya keluhan muskuloskeletal, maka diperlukan adanya perbaikan ergonomi berupa rekayasa managemen. Perbaikan ergonomi yang dilakukan adalah dengan pemberian suatu latihan tertentu sebagai upaya pencegahan dan memperbaiki sikap kerja, serta melakukan perbaikan kondisi kerja yang salah satunya berupa istirahat aktif selama 5 menit. Istirahat aktif dipilih sebagai intervensi karena istirahat aktif memiliki kelebihan yaitu dapat mengurangi kelelahan otot dan meningkatkan produktivitas (Kroemer dan Grandjean, 2000).

Latihan peregangan dinamis merupakan salah satu latihan yang dapat diberikan kepada pekerja yang telah dirancang dan disesuaikan dengan keluhan yang dirasakan oleh pekerja di industri garmen, berfokus pada motor control dan motor skills. Latihan peregangan dinamis memiliki total durasi latihan selama 15 menit dilakukan di tempat kerja sebanyak 6 kali dalam seminggu pada sore hari setelah pekerja melakukan pekerjaannya, terdiri dari 7 nama gerakan yang terbagi menjadi 11 jenis gerakan yang meliputi gerakan leher dan trunk, kontrol gerakan dari leher sampai tungkai, gerakan peregangan pada lengan sampai dengan tangan, gerakan peregangan dan kontrol gerakan pada trunk, gerakan torso pada pelvic dan kontrol pada deep core muscle lumbal, gerakan isotonik pada tungkai, serta gerakan isotonik pada ankle.

Dari latar belakang permasalahan yang terjadi pada pekerja bagian pengendalian mutu produk dan sablon di industri garmen tersebut, diperlukan penanganan berupa perbaikan ergonomi. Tujuannya untuk menghasilkan suatu produk dan jasa dalam lingkungan kerja yang efisien, efektif, nyaman, aman dan sehat. Rasa nyaman dalam bekerja akan menciptakan kualitas kerja dan produktivitas yang tinggi. Hal tersebut dapat dicapai dengan cara menerapkan sikap maupun posisi tubuh yang ergonomis pada saat bekerja dan melakukan latihan secara rutin yang dapat bermanfaat untuk mengurangi rasa sakit atau nyeri juga keluhan pada sistem muskuloskeletal (Tarwaka, 2011).

Studi yang selama ini sudah ada tentang pemberian exercise masih kurang efektif karena latihan yang diberikan hanya berfokus pada daerah punggung bawah saja, belum menyeluruh pada bagian otot-otot yang lain. Latihan tersebut belum menyertakan motor skills dalam mengatasi keluhan yang dialami oleh pekerja di industri garmen, sehingga diperlukan suatu latihan yang dapat berpengaruh pada otot-otot tubuh secara keseluruhan, mendukung dalam upaya perbaikan sikap kerja dan meminimalkan terjadinya istirahat curian. Oleh karena itu, dilakukan suatu latihan berupa latihan peregangan dinamis yang merupakan kombinasi antara teaching motor skills dan motor control exercise serta pemberian istirahat aktif dengan tujuan dapat menurunkan keluhan muskuloskeletal pada pekerja di industri garmen.

\section{METODE}

Rancangan pada penelitian menggunakan penelitian quasi eksperimental dikarenakan kelompok subjek tidak dipilih secara random dan tidak adanya kelompok pembanding. 
Rancangan penelitian quasi eksperimental yaitu dengan menggunakan rancangan sama subjek atau treatment by subject design yang dikembangkan dalam bentuk rancangan serial satu lengan dalam periode waktu yang berbeda. Keluhan muskuloskeletal antara sebelum dan sesudah intervensi dibandingkan dan dianalisis dengan uji statistik.

\section{HASIL DAN PEMBAHASAN}

Penelitian mengenai latihan peregangan dinamis dan istirahat aktif menurunkan keluhan muskuloskeletal pada pekerja dilaksanakan di industri garmen Adhi Fashion pada bulan April - Mei 2019. Penelitian melibatkan 13 orang pekerja di industri garmen Adhi Fashion yang terdiri dari 8 orang pekerja perempuan pada bagian pengendalian mutu produk $(61,54 \%)$ dan 5 orang pekerja laki-laki pada bagian sablon (38,46\%). Semua subjek memiliki keluhan muskuloskeletal pada kategori sedang sampai tinggi, serta rutin mengikuti intervensi selama proses penelitian berupa latihan peregangan dinamis dan istirahat aktif. Karakteristik subjek penelitian meliputi umur, berat badan, tinggi badan, indeks masa tubuh dan masa kerja. Hasil analisis deskriptif rerata, simpang baku dan rentangan disajikan pada Tabel 1

Tabel 1

Karakteristik Subjek Penelitian

\begin{tabular}{clcccc}
\hline No & \multicolumn{1}{c}{ Karakteristik Subjek } & $\mathrm{n}$ & Rerata & Simpang Baku & Rentangan \\
\hline 1. & Umur (Th) & 13 & 44,69 & 5,84 & $36-56$ \\
2. & Berat Badan $(\mathrm{Kg})$ & 13 & 61,21 & 8,82 & $48,6-76,7$ \\
3. & Tinggi Badan $(\mathrm{Cm})$ & 13 & 156,62 & 6,54 & $145-170$ \\
4. & Indeks Masa Tubuh $\left(\mathrm{Kg} / \mathrm{m}^{2}\right)$ & 13 & 25,01 & 3,55 & $18,48-30,22$ \\
5. & Masa kerja (th) & 13 & 9,31 & 2,90 & $7-14$ \\
\hline
\end{tabular}

$\mathrm{n} \quad=$ Jumlah sampel

Berdasarkan Tabel 1, dapat diketahui bahwa rerata usia subjek yaitu 44,69+5,84 tahun yang masih tergolong dalam usia kerja produktif. Rerata berat badan dan tinggi badan pekerja masih tergolong ideal. Indeks masa tubuh pada pekerja didapatkan hasil dari penghitungan berat badan dalam satuan kilogram dibagi dengan tinggi badan kuadarat dalam satuan meter,

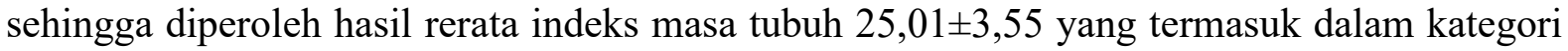
normal. Pekerja pada bagian pengendalian mutu produk dan sablon merupakan pekerja yang sudah berpengalaman karena memiliki rerata masa kerja selama lebih dari 9 tahun. Waktu kerja yang diterapkan di industri garmen Adhi Fashion yaitu 8 jam kerja/perhari dan waktu istirahat yaitu $60 \mathrm{menit} /$ hari.

Tabel 2

Analisis Uji Normalitas Data Keluhan Muskuloskeletal Menggunakan Uji Shapiro-Wilk

\begin{tabular}{lcc}
\hline \multirow{2}{*}{ Variabel } & Periode 1 & Periode 2 \\
\cline { 2 - 3 } & $\mathrm{p}$ & $\mathrm{p}$ \\
\hline Pre Keluhan musculoskeletal & 0,644 & 0,259 \\
Post Keluhan musculoskeletal & 0,973 & 0,551 \\
Selisih keluhan muskuloskeletal & 0,005 & 0,010 \\
\hline
\end{tabular}

Hasil analisis data keluhan muskuloskeletal pada pekerja bagian pengendalian mutu produk dan sablon disajikan pada Tabel 2. Uji normalitas data pada penelitian menggunakan uji Shapiro-Wilk dengan tingkat kemaknaan yaitu $\alpha=0,05$. Hasil uji normalitas data didapatkan bahwa data yang meliputi rerata keluhan muskuloskeletal sebelum bekerja (pre) dan setelah 
bekerja (post) pada Periode satu maupun Periode dua didapatkan nilai $\mathrm{p}>0,05$ yang berarti data berdistribusi normal. Sementara data selisih keluhan musculoskeletal pada Periode satu maupun Periode dua didapatkan nilai $\mathrm{p}<0,05$ yang berarti data berdistribusi tidak normal.

Uji komparasi dilakukan menggunakan uji beda kemaknaan yaitu Paired-Sampel T Test terhadap rerata keluhan muskuloskeletal (pre) pada Periode 1 dan Periode 2. Uji komparasi dilakukan untuk mengetahui kesamaan dari kondisi awal keluhan muskuloskeletal sebelum diberikan intervensi. Hasil uji komparasi rerata keluhan muskuloskeletal (pre) didapatkan nilai $\mathrm{p}=0,000$ yang berarti terdapat perbedaan bermakna keluhan musculoskeletal antara Periode 1 dan Periode $2(\mathrm{p}<0,05)$. Uji efek intervensi dilakukan untuk mengetahui pengaruh pemberian intervensi terhadap penurunan keluhan muskuloskeletal pada pekerja bagian pengendalian mutu produk dan sablon terhadap rerata selisih keluhan muskuloskeletal. Oleh karena data berdistribusi tidak normal digunakan uji statistik nonparametrik yaitu Wilcoxon Signed-Rank Test yang disajikan pada Tabel 3. Pada Tabel 3 terdapat perbedaan yang signifikan rerata pre keluhan musculoskeletal antara Periode 1 dan Periode $2(\mathrm{p}<0,05)$ yang berarti bahwa ada pengaruh latihan peregangan dinamis dan istirahat aktif terhadap penurunan keluhan muskuloskeletal pada pekerja.

Tabel 3

Uji Efek Intervensi terhadap Keluhan Muskuloskeletal Periode 1 dan Periode 2 pada Pekerja di Bagian Pengendalian Mutu Produk dan Sablon

\begin{tabular}{lcccc}
\hline \multicolumn{1}{c}{ Variabel } & $\mathrm{n}$ & Periode 1 & Periode 2 & \multirow{2}{*}{$\mathrm{p}$} \\
\cline { 3 - 4 } & & Rerata $\pm \mathrm{SB}$ & Rerata $\pm \mathrm{SB}$ & \\
\hline Pre Keluhan muskuloskeletal & 13 & $71,85 \pm 2,410$ & $66,54 \pm 2,066$ & 0,001 \\
Selisih keluhan muskuloskeletal & 13 & $5,77 \pm 0,689$ & $4,85 \pm 0,801$ & 0,018 \\
\hline
\end{tabular}

$\mathrm{n} \quad=$ Jumlah sampel

$\mathrm{SB}=$ Simpang Baku

Berdasarkan Tabel 3, menunjukkan bahwa terdapat perbedaan rerata pre keluhan muskuloskeletal antara Periode 1 dan Periode 2. Hal ini disebabkan oleh latihan peregangan dinamis selama enam hari yang dilakukan setelah jam kerja berakhir dan penerapan istirahat aktif selama dua kali dalam hari selama enam hari yang dilakukan disela aktivitas pekerjaan berdampak positif pada keluhan muskuloskeletal, tidak hanya dalam mengurangi keluhan muskuloskeletal pada efek akut tetapi juga pada efek kronis. Hal ini disebabkan oleh latihan peregangan dinamis merupakan intervensi yang sudah disesuaikan untuk memperbaiki kondisi yang dialami oleh pekerja. Selain itu intervensi berupa latihan tersebut juga dapat dilakukan secara mandiri oleh pekerja baik di rumah maupun di tempat kerja.

Latihan peregangan dinamis dan istirahat aktif merupakan intervensi yang dapat digunakan sebagai upaya pencegahan sekaligus upaya perbaikan/terapi. Penurunan keluhan muskuloskeletal dibuktikan dengan penurunan rerata keluhan muskuloskeletal (pre) dan (post) serta perbandingan nilai minimum dan nilai maksimum antara Periode 1 dan Periode 2. Pada Periode satu rerata keluhan muskuloskeletal (pre) didapatkan hasil 71,85 $\pm 2,41$ dengan nilai minimum 67 dan nilai maksimum 75, sedangkan rerata keluhan muskuloskeletal (post) didapatkan hasil 77,62 $\pm 3,15$ dengan nilai minimum 72 dan nilai maksimum 83 . Selisih keluhan

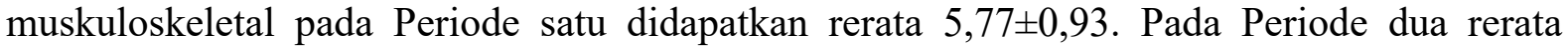
keluhan muskuloskeletal ( pre) didapatkan hasil 66,54 $\pm 2,06$ dengan nilai minimum 62 dan nilai maksimum 69, sedangkan rerata keluhan muskuloskeletal (post) didapatkan hasil 71,38 $\pm 2,43$ dengan nilai minimum 67 dan nilai maksimum 75. Selisih keluhan muskuloskeletal pada Periode dua didapatkan rerata 4,85 $\pm 0,80$. 
Selama proses penelitian berlangsung, pengisian Nordic Body Map dilakukan secara mandiri oleh pekerja yang setelah sebelumnya diberikan penjelasan tentang tata cara pengisian kuesioner tersebut. Pekerja pada saat mengisi kuesioner didampingi oleh peneliti untuk memastikan pengisian Nordic Body Map sudah tepat dengan cara melakukan wawancara kepada masing-masing pekerja. Hasil latihan peregangan dinamis dan istirahat aktif terhadap penurunan keluhan muskuloskeletal pekerja bagian pengendalian mutu produk dan sablon di industri garmen Adhi Fashion dilihat berdasarkan Tabel Klasifikasi Tingkat Risiko Keluhan Muskuloskeletal pada Periode satu didapatkan 9 orang pekerja memiliki tingkat risiko 3 dengan klasifikasi keluhan pada kategori tinggi dan 4 orang pekerja memiliki tingkat risiko 2 dengan klasifikasi keluhan pada kategori sedang. Sementara pada Periode dua didapatkan 13 orang pekerja memiliki tingkat risiko 2 dengan klasifikasi keluhan pada kategori sedang.

Keluhan muskuloskeletal merupakan faktor yang dapat menyebabkan turunnya produktivitas kerja, hilangnya jam kerja, tingginya biaya pengobatan dan material, serta rendahnya kualitas kerja (Samara, 2007). Salah satu usaha yang memiliki risiko terjadinya kelelahan kerja dan keluhan muskuloskeletal yang cukup tinggi adalah usaha sektor informal, khususnya industri jahitan maupun industri garmen. Lokasi keluhan muskuloskeletal yang paling banyak dialami oleh pekerja bagian pengendalian mutu produk dan sablon di industri garmen Adhi Fashion adalah sakit pada bahu sebanyak 84,62\%, tangan sebanyak 76,92\%, leher bawah sebanyak $76,92 \%$, betis sebanyak $69,23 \%$, pinggang sebanyak $61,54 \%$, dan lutut sebanyak 53,85\%.

Penurunan kemampuan gerak disebabkan karena adanya kerusakan yang berupa ketegangan otot, inflamasi, degenerasi, maupun fraktur pada tulang yang disertai dengan rasa nyeri (Rozana dan Adiatmika, 2014). Keluhan muskuloskeletal timbul karena frekuensi atau periode waktu yang lama dari usaha otot dalam menerima beban statis yang terjadi secara terus menerus menyebabkan kerusakan secara tiba-tiba, serta adanya aktivitas berat atau pergerakan yang tak terduga, sehingga dapat menyebabkan kelelahan dan keletihan otot.

Hal lain terkait munculnya keluhan muskuloskeletal adalah ketika tubuh seseorang terpaksa menerima beban pada postur yang salah selama melakukan aktivitas kerja, serta ketika tidak ada kemungkinan untuk mendapatkan bantuan atau mengubah postur tubuh (Kumar, 2007). Jika tuntutan pekerjaan memerlukan ketelitian, akan menyebabkan leher fleksi terusmenerus dan beban kerja otot statis dalam jangka panjang pada otot ekstensor leher dan tidak ada kesempatan merilekskan otot-otot untuk beristirahat. Oleh karena itu akan menyebabkan periode kerja yang lebih pendek dan jeda waktu istirahat yang lebih lama.

Latihan peregangan dinamis dapat menurunkan keluhan muskuloskeletal karena menyebabkan terjadinya peningkatan sirkulasi darah pada otot yang secara berangsur-angsur akan menurunkan spasme otot, sehingga derajat nyeri menurun. Latihan peregangan dapat mengurangi spasme otot karena teraktivasinya propioseptor otot atau muscle spindle. Muscle spindle bertugas untuk mengatur sinyal ke otak tentang perubahan panjang otot dan perubahan tonus yang mendadak berlebihan.

Peregangan yang dilakukan berlawanan arah dengan posisi statis dapat mencegah ketidakseimbangan pada otot dan mencegah terjadinya keluhan musculoskeletal (Valachi, 2003). Selain itu, peregangan dapat menimbulkan beberapa efek pada tubuh seperti meningkatnya aliran darah menuju otot sehingga meningkatkan suplai nutrisi dan oksigen pada otot dan diskus vertebralis, meningkatnya produksi cairan sinovial pada sendi, mengurangi terjadinya trigger point, menjaga lingkup gerak sendi, dapat menimbulkan respon rileks pada sistem saraf pusat, memanaskan otot sebelum memulai pekerjaan, serta dapat mengidentifikasi struktur yang menegang yang dapat mengarah pada cedera.

Setidaknya diperlukan kontraksi dari $50 \%$ otot pada tubuh untuk mempertahankan postur. Peregangan yang dilakukan selama 15-30 detik secara perlahan dapat mengurangi ketegangan pada otot. Selain itu, salah satu faktor yang berperan dalam timbulnya keluhan 
muskuloskeletal yaitu berkurangnya aliran nutrisi dan oksigen pada otot. Peregangan dapat dilakukan untuk meningkatkan aliran darah menuju jaringan sehingga dapat meningkatkan efisiensinya dalam menghantarkan nutrisi dan oksigen ke jaringan otot (Kumar, dkk., 2014).

Berdasarkan fisiologi, kelelahan kerja akumulasi zat sisa metabolisme dapat menyebabkan kinerja otot menurun serta mempermudah timbulnya kelelahan. Gerakan peregangan yang dilakukan bertujuan untuk membantu relaksasi otot, sehingga otot lebih lentur dalam bergerak karena peningkatan suplai oksigen, serta alan meningkatkan kelenturan yaitu kemampuan untuk menggerakkan otot beserta persendian pada seluruh daerah pergerakan.

Istirahat aktif dapat menurunkan keluhan muskuloskeletal karena pada saat pekerja melakukan aktivitas berjalan mengambil air minum, otot memiliki kesempatan untuk relaksasi dari sikap kerja yang monoton dan statis yang dilakukan dalam waktu lama secara terusmenerus. Dalam melakukan pekerjaannya, waktu kerja disesuaikan dengan aturan yang sudah ditetapkan.

\section{SIMPULAN}

Berdasarkan hasil penelitian dan analisis data dapat disimpulkan bahwa latihan peregangan dinamis dan istirahat aktif menurunkan keluhan muskuloskeletal pada pekerja bagian pengendalian mutu produk dan sablon sebesar 7,72\%

Disarankan latihan peregangan dinamis dan istirahat aktif dilakukan secara rutin oleh seluruh pekerja di industri garmen agar dapat meminimalkan terjadinya keluhan yang ditimbulkan akibat aktivitas kerja.. Untuk penelitian selanjutnya dapat melakukan perbaikan berupa rekayasa teknik pada kondisi pencahayaan maupun workstation di industri garmen.

\section{DAFTAR PUSTAKA}

Kroemer, K.H.E dan Grandjean E. 2000. Fitting The Task To The Man. A Textbook of Occupational Ergonomics ( $4^{\text {th }}$ ed). New York: CRC Taylor \& Francis.

Kumar D.K., Rathan N., Mohan S., Begum M., Prasad B., dan Prasad E.R.V. 2014. Exercise prescriptions to prevent musculoskeletal disorders in dentists. J Clin Diagnostic Res, Vol. 8(7):13.

Kumar, S. 2007. Biomechanics in Ergonomics ( $2^{\text {nd }}$ ed). London: CRC Press Taylor \& Francis Group.

OSHA 3125. 2000. Ergonomic: The Study of Work. In: United State of America: U.S. Department of Labor Occupational Safety and Health Administration.

Rozana, F. dan Adiatmika IP.G. 2014. Tingkat Kelelahan Dan Keluhan Muskuloskeletal Pada Penjahit Di Kota Denpasar Provinsi Bali. Denpasar: Fakultas Kedokteran Universitas Udayana.

Samara, D. 2007. Nyeri Muskuloskeletal pada Leher Pekerja dengan Posisi Pekerjaan yang Statis. Universa Medicina, Vol. 26(3):137-142.

Tarwaka. 2011. Ergonomi Industri: Dasar-dasar Pengetahuan Ergonomi dan Aplikasi di Tempat Kerja. Surakarta: Uniba Press.

Valachi, B. dan Valachi, K. 2003. Preventing musculoskeletal disorders in clinical dentistry: Strategies to address the mechanisms leading to musculoskeletal disorders. Journal of the American Dental Association, Vol. 134:1604-1612. 